\title{
Field hospital wastewater treatment scenario
}

\author{
Nadeem Ahmad Khan ${ }^{1 *}$, Sirajuddin Ahmed ${ }^{1}$, Sergij Vambol' ${ }^{2}$, Viola Vambol${ }^{2}$, Izharul Haq Farooqi ${ }^{3}$ \\ ${ }^{1}$ Jamia Millia Islamia, New Delhi, India \\ ${ }^{2}$ Public Agency "National Scientific and Research Institute of Industrial Safety and Occupational Safety and Health", \\ Kiev, Ukraine, \\ ${ }^{3}$ Aligarh Muslim University, Uttar Pradesh, India \\ *email: er.nadimcivil@gmail.com
}

Received: 22 June 2019 / Accepted: 22 August 2019

\begin{abstract}
In extreme situations with a large number of victims, field hospitals are deployed to provide patients with medical treatment. The large number of patients with different types of medications used generates the problem of hospital waste accumulation, including hospital wastewater (HWW). Wastewater is water having compromised characteristics that adversely affect the environment. Many countries do not have strict regulations regarding the disposal of hospital effluent, which contains pathogens, toxic chemicals and radioisotopes. The disposal of such substances poses a serious threat to public health and the environment. This paper discusses the possibilities of field hospital wastewater management development. Micropollutants, including pharmaceuticals, are found in different ecosystem elements, like soil, surface and ground water, drinking water as well as treated effluent from conventional wastewater treatment plants. Wastewater discharged from different health facilities, with varying concentrations of pharmaceuticals, is often mixed with municipal sewage, thus remains untreated even after passing through conventional treatment plants. Extensive experience in the application of different types of HWW treatment methods allows the development of an optimal treatment scenario for field hospital wastewater problem resolution, including the combination of Microbiological Reactor and Fenton Process technologies. They are applicable in the case of low wastewater flow rate values, specific for field hospital conditions.
\end{abstract}

Key words: environment, pollution, waste management, disposal, pharmaceutical micropollutants.

\section{Introduction}

One of the most important tasks to be resolved at zones of liquidation of extreme situations is providing rescue work and emergency medical care to victims (Bar-On et al., 2013; Sokolov et al., 2018). For such purpose the rescue units are supplied with mobile hospitals having ability of fast delivery and deployment at needed location. Primary task of mobile hospital is to evaluate patient's state of health. Depending on the evaluation result, they must provide patient with urgent care right at place and send him to stationary health facility for definitive treatment.

Extreme situations with large number of victims and wide spreading territory like natural disasters such hospital should be transformed into field one to provide definitive treatment right at place (Bar-On et al., 2013; Halpern et al., 2003; Naor et al., 2017). Multiple patients with different sorts of medications used bring up the problem of hospital wastes accumulation including hospital wastewater (HWW) (Halpern et al., 2003; Naor et al., 2017; Vambol et al., 2018; Vambol et al., 2019). Nowadays these emerging pollutants are still not being regulated neither for stationary hospitals nor for field or mobile ones.

In any health facility, the water is used in various places like wards, surgery, laboratories, kitchens, etc. During consumption, its characteristics change drastically (Fekadu et al., 2015). The types of HWW are presented in Figure 1.

In comparison with domestic sewage the hospital effluent raises much higher danger as it contains wide variety of toxic substances like antibiotics, radionuclides, and 
disinfectants (Chonova et al., 2016; Santos et al., 2013; Verlicchi et al., 2012a; ICRP, 2004). In certain study (Verlicchi et al., 2010b) they have highlighted that the range of such micropollutant is much higher than the one of domestic sewage by 4-150 times. Presence of drug's residues is caused mainly due to undigested drugs excreted with human excreta (Maheshwari et al., 2016). Yet the hospital effluent in general terms should be considered as the breeding ground for pathogenic bacteria. As field hospitals have higher use of antibiotics for treatment of patients the rate of environmental pollution for them is much more critical.

\section{Methodology}

This paper covers some aspect about the HWW treatment scenarios toward effluent discharge that are most suitable nowadays for field hospital wastewater treatment. The investigation was carried out using analytical analysis.

\subsection{Hospital wastewater occurrences}

Common micropollutant occurrence including pharmaceuticals are found in different elements of ecosystem like soils, surface and ground waters, drinking water as well as treated effluent from conventional wastewater treatment plants (Kümmerer, 2009a, b). There are various possible routes for exposure in an ecosystem. But most expected source is through the consumers consumption and excretion, which is transported to sewers (Kümmerer, 2009a, b). There might be another route like leaking from treatment units, application of biosolids in fields, leaking from septic tanks or even lack of any treatment equipment (Jones-Lepp et al., 2009, 2010, 2012; Jones-Lepp \& Stevens, 2007; Kümmerer, 2010).

The assessment of drugs and its residues in HWW can be done either with predicted or measured concentration (Verlicci \& Zambello, 2016). Predicted concentration value is based on water consumption per bed, excretion percent etc., whereas measured concentration value is found by sample collection and laboratory analysis. Predicted and measured concentrations may provide different information due to influence of time scale selected. Predicted concentrations are calculated on yearly basis while measured concentration is found for specific period of time. But in some aspect predicted concentration is better for evaluation of discharge of drugs and their residues through longer period (Hermann et al., 2015).

Too many pharmaceuticals are available so prioritization strategies need to be adopted considering various parameters like ecotoxicity, risk, biological and physicochemical characteristics and resistance towards treatment (Al et al., 2014; Kümmerer \& Helmers, 2000). The mounting evidence about the resistant genes, genetic lesions and impact had made to rethink about this HWW discharging to streams (Boxall et al., 2012; Brodin et al., 2013; Cizmas et al., 2015; Galus et al., 2013a, b; Parolini et al., 2013).

\subsection{Regulation standards around the globe}

The regulation pattern is variable depending upon the various factors in different countries. The margin between the

\section{Hospital wastewater}

\section{Non-infectious}

- Generated from packaging, cooking and visitors' activities

- Its quantity is huge, much larger than for infectious one

- Recyclable, but may be polluted with infectious agents

\section{Infectious}

- Incorporates pathogens in quantities high enough to transmit infectious diseases

- Consists of cultures and spatulas of infectious markers from laboratory paintings,surgical and autopsy wastes

Figure 1. Schematic diagram showing types of hospital wastewater 
disposal of sewage and wastewater having active pharmaceutical ingredients is very narrow and is a debatable issue. No clear boundary definition makes confusion towards legislative norms about the HWW in terms of management (Ministry of Environment and Forest, Government of India, New Delhi, 1986).

If we look around, we will see that even Europe lacks behind specific guidelines in managements of such wastewater except some directives (EU, 1991; EU, 1998). They generally consider collection and treatment of effluent for population greater than 2,000 , secondary treatment of all discharges and advance treatment for population greater than 1,000 , pre-authorization discharge from various industries and monitoring the efficiencies of existing treatment systems (EU, 2008).

Due to non-existence of specific guidelines in European Union, its members have adopted their own regulations on evaluation and disposal criteria for HWW. In Germany, HWW is considered as domestic wastewater, thus no prior authorization is needed (Federal Ministry for the Environment, Nature Conservation and Nuclear Safety, Germany, 2004). In some case, if HWW meets certain characteristics with respect of sewage then they discharge it to water treatment plant without any further consideration (Carraro et al., 2016). In Italy, if health facility capacity is less or equal to 50 beds then HWW is discharged as sewage without certain analysing. Such HWW is treated along with domestic sewage in conventional treatment plants (Italy, 2011).

In China, HWW is considered as industrial effluent. Then they take F-coliform bacteria as indicator of ecotoxicity for 50 bed health facility (China, 1998).

In Vietnam, they have specific legislation regarding management and treatment of HWW (The Socialist Republic of Vietnam, 2014). The law indicates that hospital needs to collect and treat effluent according to the treatment standards. On the other hand, the law was made to regulate the HWW collection in water bodies.

The World Health Organization guidelines are much more clear (Chartier et al., 2014). It clearly states collection and disposal of healthcare wastewater divided into three heads: (1) Blackwater having high pollutant load with faecal matter; (2) Greywater as diluted form generated from washing, bathing, laboratories, x-rays film cleaning, etc.; (3) Storm water, which is actually not a form of wastewater but represents rainfall collection on ground surface. They can be utilized in different forms but HWW might contain different levels of contamination in relation with service level and tasks of medical facilities. The main risk associated with HWW in developing countries where unmonitored disposal schemes were in practice, which might pollute both ground and underground aquifers. The best way of HWW management is to treat it on-site. The document also provides details about sludge disposal, possi- ble reuse, including the application of new and innovative HWW treatment technologies. It also provides guidance for minimum approach for HWW management in developing countries where patients do not have proper sanitation facilities.

In USA, Clean Water Act is governing law regarding discharges (Clean Water Act, 1972). It also considers the local pre-treatment schemes and regulations including discharge permits. The discharging unit has to follow these local regulations as well as the technology-based standards set up on national level. Medical facilities discharges HWW into sewer line are considered to be indirect discharges. Direct discharges are those put directly into rivers, ponds, etc. These regulations were reviewed annually with technological advancement in the treatment field. The main objective is to modify current disposal standards, categories of discharge for law framing and identifying new indirect discharges for pre-treatment standard development (EPA, 2016). Health facilities are designated by local sewer authority as significant industrial user, who has to submit its discharging effluent characteristics report twice to the authority.

Any health facility making direct discharges into natural water bodies has to follow national discharge standards. Their requirements are quite strict as compared to indirect standards. Generally they are not met by in-field mobile hospitals because they are not being monitored or treated by municipal systems.

\subsection{Hospital wastewater treatment scenarios around the world}

Multiple researches were carried out in this field (Adamcza et al., 2012; Batelaan et al., 2013; Beyene \& Redaie, 2011; Duong et al., 2008; Göbel et al., 2007; Gracepavithra et al., 2017; Grundfos BioBooster A/S, 2015; Kosma et al., 2010; Lien et al., 2016; Liu et al., 2010; Mahvi et al., 2009; Martins et al., 2008; Prabhasankar et al., 2016; Prado et al., 2011; Shrestha et al., 2001a; Sim et al., 2013; Tambosi et al., 2009; Verlicchi et al., 2010a; Yu et al., 2013). However, they mostly deal with exploring different characteristics, compositions and the risk imposed with HWW and their residues in comparison with domestic sewage.

Conventional treatment plants efficiencies are investigated same as new technologies to be applied. However, the past studies were concentrated only on some of the chemical effluents leaving behind most of them, which are nowadays commonly used in health facilities. The main cause of this limitation is the lack of detection techniques and consumption pattern data.

The micropollutant removal efficiency depends on biodegradability, physicochemical properties, solubility, adsorption ability, $\mathrm{pH}$, temperature and retention time. The characteristics of HWW effluents are dependent on topog- 
raphy and some physical, chemical, biological and microbiological parameters. Maximum values of these parameters, detected in different studies (Carraro et al., 2016; Verlicchi et al., 2010b, 2012b; Lenz et al., 2007; Daouk et al., 2016; El-Ogri et al., 2016), are mentioned in Table 1.

HWW physicochemical characteristics are comparable with the domestic wastewater. Nowadays the presence of micropollutants in HWW is mainly focused on due to their low biodegradability, antibiotic-resistant genes and associated factors like cancer, mutagen ones, etc. Till date, there are hardly any norms for the concentration of pharmaceuticals in wastewater.

The methods to be applied to organic contaminants of HWW during sewage and industrial effluent treatment (Rogers, 1996) are presented in Figure 2.
Different technologies based on enlisted methods are in use acting as primary, secondary and tertiary steps of HWW treatment scenarios. The type of sequences adopted for the combination of various treatments related to HWW depends on the economic condition of the country. The most widely used technology is Conventional Activated Sludge (CAS) followed by Membrane Biological Reactor (MBR). Micropollutants removal efficiency values vary from higher for some drugs to lower for another ones. But there are no specific technology considered as proper solution for HWW problem. Table 2 indicates different treatment scenarios adopted globally on full scale.

In Table 3 the results of comparison of adopted single stage HWW treatment schemes are represented.

Table 1. Characteristics of hospital wastewater

\begin{tabular}{|c|c|c|}
\hline No. & Parameters observed & $\begin{array}{c}\text { Maximum value } \\
\text { detected }\end{array}$ \\
\hline 1. & Chemical oxygen demand, $\mathrm{g} / \mathrm{m}^{3}$ & 7,764 \\
\hline 2. & Dissolved organic carbon concentration, $\mathrm{g} / \mathrm{m}^{3}$ & 130 \\
\hline 3. & Total organic carbon concentration, $\mathrm{g} / \mathrm{m}^{3}$ & 180 \\
\hline 4. & Biochemical oxygen demand, $\mathrm{g} / \mathrm{m}^{3}$ & 2,575 \\
\hline 5. & Biochemical and chemical oxygen demands ratio & 0.4 \\
\hline 6. & Adsorbable organic halides concentration, $\mathrm{mg} / \mathrm{m}^{3}$ & 10,000 \\
\hline 7. & Chlorine concentration, $\mathrm{g} / \mathrm{m}^{3}$ & 400 \\
\hline 8. & Nitrite concentration, $\mathrm{g} / \mathrm{m}^{3}$ & 0.6 \\
\hline 9. & Nitrate concentration, $\mathrm{g} / \mathrm{m}^{3}$ & 2 \\
\hline 10. & Total suspended solids, $\mathrm{g} / \mathrm{m}^{3}$ & 3,260 \\
\hline 11. & E. coli presence measure, most probable number per $100 \mathrm{~cm}^{3}$ & 106 \\
\hline 12. & Total coliform presence measure, most probable number per $100 \mathrm{~cm}^{3}$ & 107 \\
\hline 13. & Gadolinium concentration, $\mathrm{mg} / \mathrm{m}^{3}$ & 300 \\
\hline 14. & Mercury concentration, $\mathrm{mg} / \mathrm{m}^{3}$ & 8 \\
\hline 15. & Copper concentration, $\mathrm{mg} / \mathrm{m}^{3}$ & 230 \\
\hline 16. & Nickel concentration, $\mathrm{mg} / \mathrm{m}^{3}$ & 71 \\
\hline 17. & Lead concentration, $\mathrm{mg} / \mathrm{m}^{3}$ & 19 \\
\hline 18. & Zinc concentration, $\mathrm{mg} / \mathrm{m}^{3}$ & 670 \\
\hline 19. & Naproxen concentration, $\mathrm{mg} / \mathrm{m}^{3}$ & 11 \\
\hline 20. & Diclofenac concentration, $\mathrm{mg} / \mathrm{m}^{3}$ & 15 \\
\hline 21. & Ciprofloxacin concentration, $\mathrm{mg} / \mathrm{m}^{3}$ & 125 \\
\hline 22. & Erythromycin concentration, $\mathrm{mg} / \mathrm{m}^{3}$ & 83 \\
\hline 23. & Norfloxacin concentration, $\mathrm{mg} / \mathrm{m}^{3}$ & 44 \\
\hline 24. & Ofloxacin concentration, $\mathrm{mg} / \mathrm{m}^{3}$ & 35 \\
\hline 25. & Penicillin $\mathrm{G}$ concentration, $\mathrm{mg} / \mathrm{m}^{3}$ & 5 \\
\hline 26 & Tetracycline concentration, $\mathrm{mg} / \mathrm{m}^{3}$ & 4 \\
\hline 27. & Carbamazepine concentration, $\mathrm{mg} / \mathrm{m}^{3}$ & 2 \\
\hline 28. & Glibenclamide concentration, $\mathrm{mg} / \mathrm{m}^{3}$ & 11 \\
\hline 29. & Penciclovir concentration, $\mathrm{mg} / \mathrm{m}^{3}$ & 0.01 \\
\hline 30. & Cyclophosphamide concentration, $\mathrm{mg} / \mathrm{m}^{3}$ & 2 \\
\hline 31. & Doxifluridine concentration, $\mathrm{mg} / \mathrm{m}^{3}$ & 0.08 \\
\hline 32. & Tamoxifen concentration, $\mathrm{mg} / \mathrm{m}^{3}$ & 0.17 \\
\hline 33. & Tegafur concentration, $\mathrm{mg} / \mathrm{m}^{3}$ & 0.09 \\
\hline
\end{tabular}




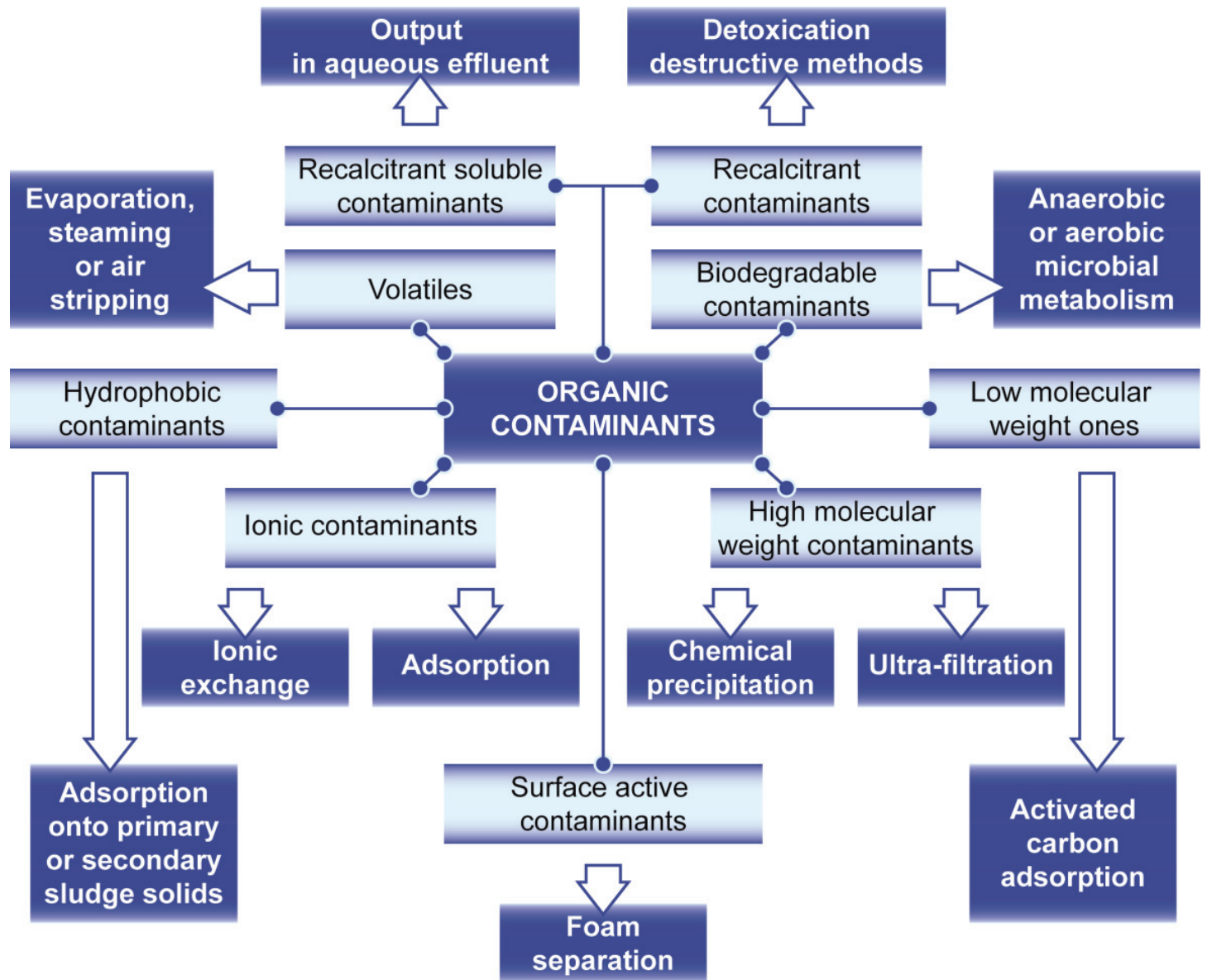

Figure 2. Methods of hospital wastewater organic contaminants neutralization during sewage and industrial effluent treatment

Table 2. Hospital wastewater treatment scenarios adopted globally on full scale

\begin{tabular}{|c|c|c|c|}
\hline No. & Country & Treatment schemes & References \\
\hline 1. & China & $\begin{array}{c}\text { MBR }+ \text { Chlorination } \\
\text { CAS + MBR }\end{array}$ & (Liu et al., 2010; Yu et al., 2013) \\
\hline 2. & Ethiopia & Ponds & (Beyene \& Redaie, 2011) \\
\hline 3. & India & CAS + Sand filtration & (Prabhasankar et al., 2016) \\
\hline 4. & Iran & CAS + Chlorination & (Mahvi et al., 2009) \\
\hline 5. & Nepal & $\begin{array}{c}\text { Septic tank + horizontal subsurface flow + vertical } \\
\text { subsurface flow }\end{array}$ & (Duong et al., 2001b) \\
\hline 6. & Vietnam & CAS & (Sim et al., 2013) \\
\hline 7. & Republic of Korea & $\begin{array}{c}\text { Flocculation + activated carbon } \\
\text { Flocculation }+ \text { CAS }\end{array}$ & \\
\hline
\end{tabular}


As it may be seen, the most effective single stage method is Ozonation Process (OP) providing up to $91 \%$ efficiency of pharmaceuticals removal. In this method, ozone oxidizes micropollutants directly or indirectly on hydroxyl radical acting as strong oxidizing agent. Ozone reaction pathway is shown in Figure 3.
However, OP method has certain practical complexities for in-field application. First of all, its cost is high. In addition, ozone is a toxic gas, which means necessity of strict safety control application and corresponding qualification level of those who use it. Thus in most cases they use MBR treatment method as the biological stage of combined removal process.

Table 3. Single stage HWW treatment schemes comparison

\begin{tabular}{|c|c|c|c|}
\hline No. & $\begin{array}{c}\text { Treatment adopted } \\
\text { Single stage removal } \\
\text { efficiency }\end{array}$ & References \\
\hline \multicolumn{4}{|c|}{ Biological treatment adopted } \\
\hline 1. & MBR & $39-60 \%$ & (Göbel et al., 2007) \\
\hline 2. & Filtration + CAS & $59-76 \%$ & (Lien et al., 2016) \\
\hline 3. & Flocculation + CAS + Activated Carbon & $80 \%$ & \\
\hline \multicolumn{2}{|c|}{ Physicochemical treatment adopted 2013$)$} \\
\hline 4. & OP & $91 \%$ & (Gracepavithra et al., 2017) \\
\hline
\end{tabular}

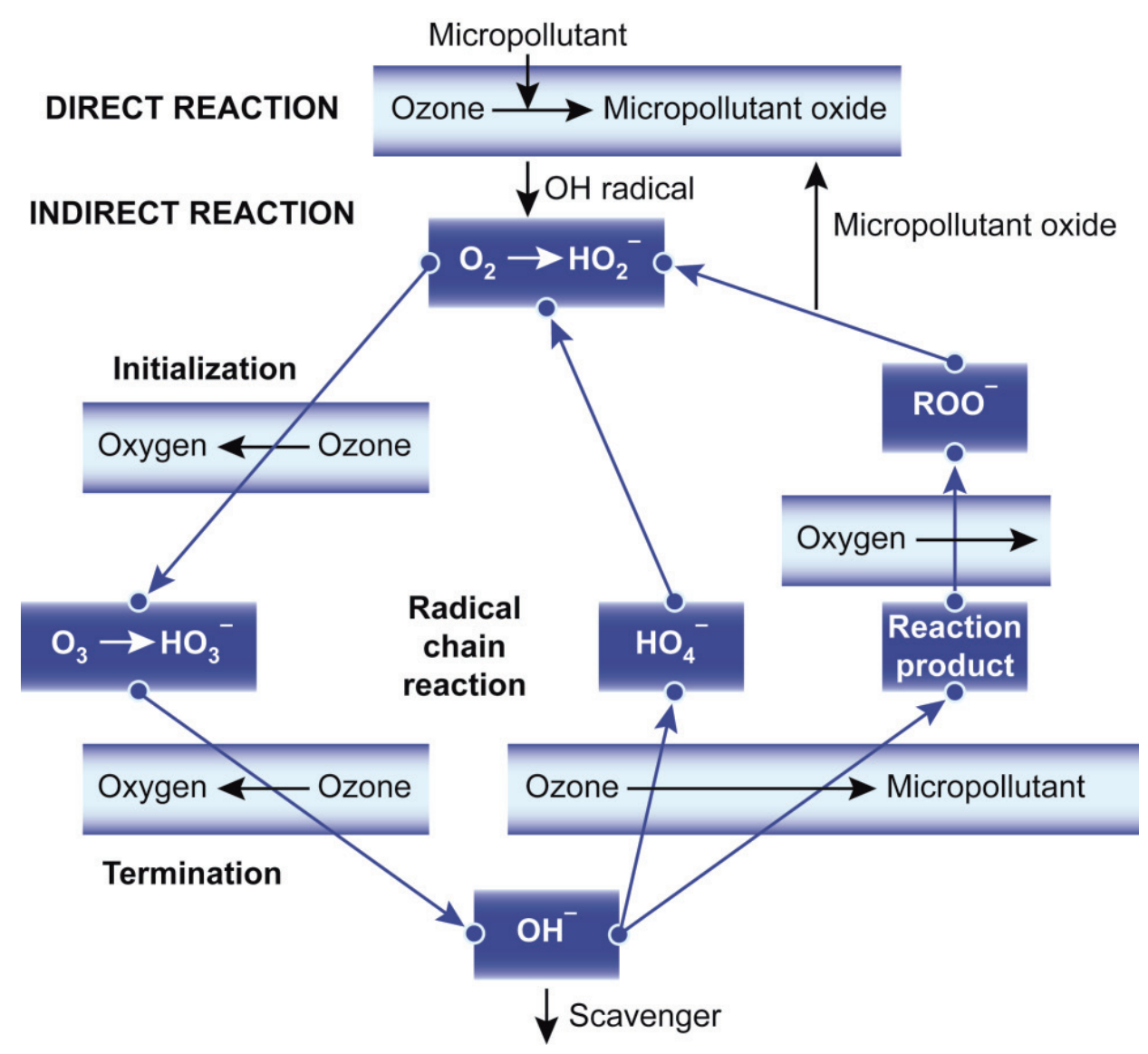

Figure 3. Ozone reaction pathway 
In Table 4 the results of comparison of adopted combined HWW treatment schemes are shown. The basic biological stage of HWW treatment scenario is formed by one of four methods including MBR, Septic tank application, Upflow Anaerobic Sludge Blanket (UASB) and CAS. Various physical and physicochemical methods are considered in studies, including CAS, Granulated Activated Carbon (GAC), Powdered Activated Carbon (PAC), Ultraviolet (UV) radiation, OP, Fenton Process (FP), Chlorination, Anaerobic filters and Wetlands application.

Selection of physicochemical treatment depends upon characteristics of treated wastewater (Hancock, 1999) shown in Figure 4.

Adsorption using activated carbon is quite an old method of treatment of pollutants. In adsorption, molecularlevel attraction leads to binding of the soluble and gaseous chemical substances on the adsorbing surface. Activation of carbon results in a porous structure, which enhances the adsorption capabilities. The types and uses of activated carbon are shown in Figure 5.

Fenton treatment process involves the reaction of hydrogen peroxide with iron to produce its radical.

Photo-Fenton process is a promising treatment opportunity in the elimination of a various type of pharmaceuticals. As in HWW treatment, the main challenge is to treat micropollutant effectively considering the cost aspect. Fenton process is not only used in the elimination of various microcontaminants dissolved in water or wastewater but is also simpler method.

New approach is economical as the chemical rate for hydrogen ion requires great attention for modification, mainly for the procedure of treatment process. Pre-treatment of effluent enables Photo-Fenton Process (see Fig. 6) act at lower costs, decreased reactor size and amount of reagents required.

\section{Results and Discussion}

\subsection{The lack of hospital wastewater treatment regulations}

The lack of specific laws for HWW is that it is considered as domestic waste in some cases and as industrial one in another. For field hospitals specific HWW management guidelines are to be developed indicating certain characteristics that can be represented to specify its nature.

The HWW discharge to the natural water bodies are considered to be the most important risk due to the generation of antibiotic resistant genes in bacteria and the raise of

Table 4. Combined hospital wastewater treatment schemes comparison

\begin{tabular}{|c|c|c|c|c|}
\hline No. & $\begin{array}{l}\text { Biological } \\
\text { treatment }\end{array}$ & Physicochemical treatment & $\begin{array}{c}\text { Combined removal } \\
\text { efficiency }\end{array}$ & References \\
\hline 1. & \multirow{7}{*}{ MBR } & $\mathrm{OP}+\mathrm{GAC}$ & up to $70 \%$ & (Batelaan et al., 2013) \\
\hline 2. & & $\begin{array}{c}\mathrm{OP}+\mathrm{PAC}+\text { Sand filtration } \\
\mathrm{PAC}+\text { Sand filtration }\end{array}$ & up to $80 \%$ & (Adamcza et al., 2012) \\
\hline 3. & & $\mathrm{OP}+\mathrm{UV}$ & $50-90 \%$ & (Verlicchi et al., 2010a) \\
\hline 4. & & $\mathrm{GAC}+\mathrm{OP} / \mathrm{FP}+\mathrm{UV}$ & up to $90 \%$ & $\begin{array}{c}\text { (Grundfos BioBooster A/S, } \\
\text { 2015) }\end{array}$ \\
\hline 5. & & $\mathrm{GAC}+\mathrm{UV}$ & up to $90 \%$ & $\begin{array}{c}\text { (Grundfos BioBooster A/S, } \\
\text { 2015) }\end{array}$ \\
\hline 6. & & Chlorination & $95 \%$ & (Liu et al., 2010) \\
\hline 7. & & FP/UV & $12-100 \%$ & (Tambosi et al., 2009) \\
\hline 8. & \multirow{3}{*}{ Septic tank } & Oxidation ponds & $54 \%$ & (Beyene \& Redaie, 2011) \\
\hline 9. & & Anaerobic filters & $65 \%$ & (Martins et al., 2008) \\
\hline 10. & & Wetlands & up to $77 \%$ & (Shrestha et al., 2001b) \\
\hline 11. & UASB & Anaerobic filters & $64 \%$ & (Prado et al., 2011) \\
\hline 12. & CAS & Chlorination & $65-92 \%$ & $\begin{array}{c}\text { (Göbel et al., 2007; Kosma } \\
\text { et al., 2010; Shrestha et al., } \\
\text { 2001a) }\end{array}$ \\
\hline
\end{tabular}




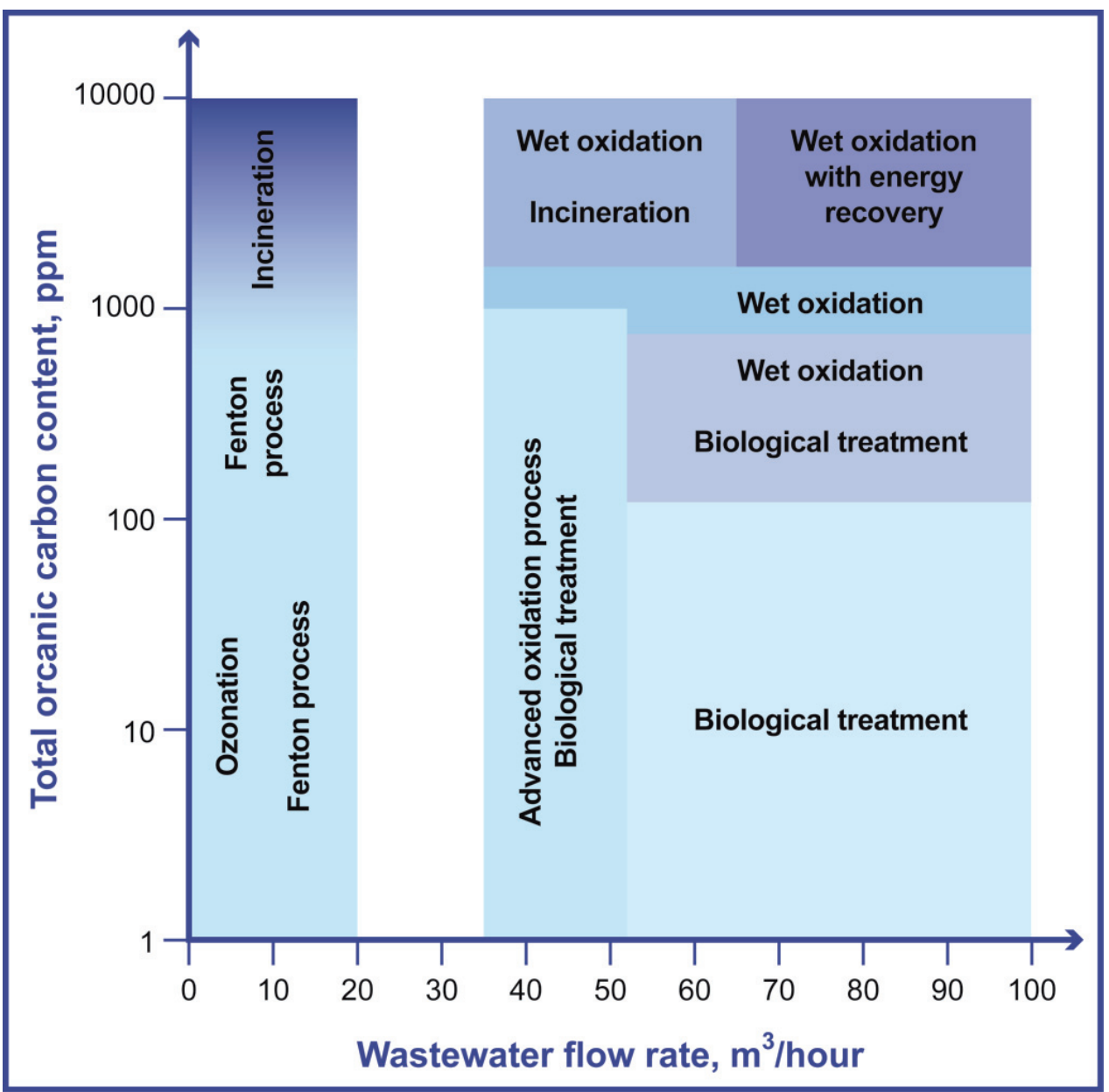

Figure 4. Physicochemical treatments application depending upon Total organic carbon content and Wastewater flow rate

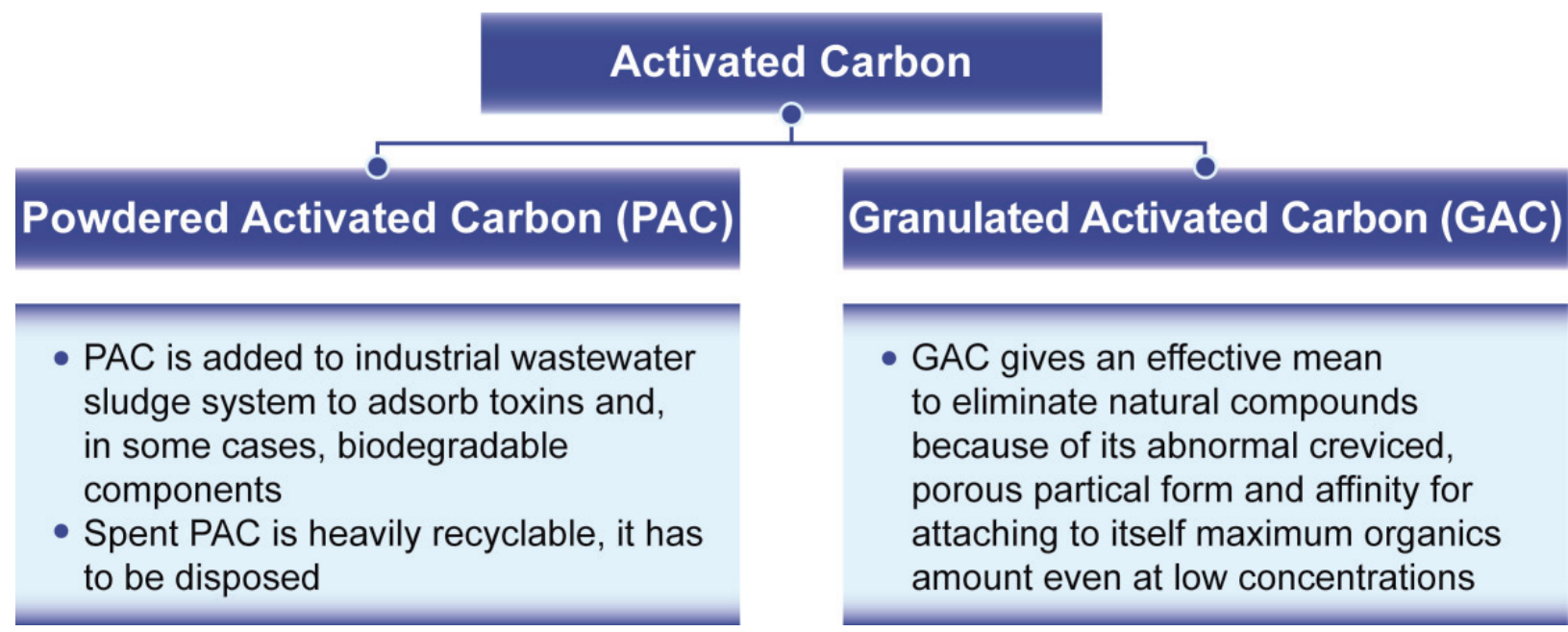

Figure 5. Activated Carbon types and uses 


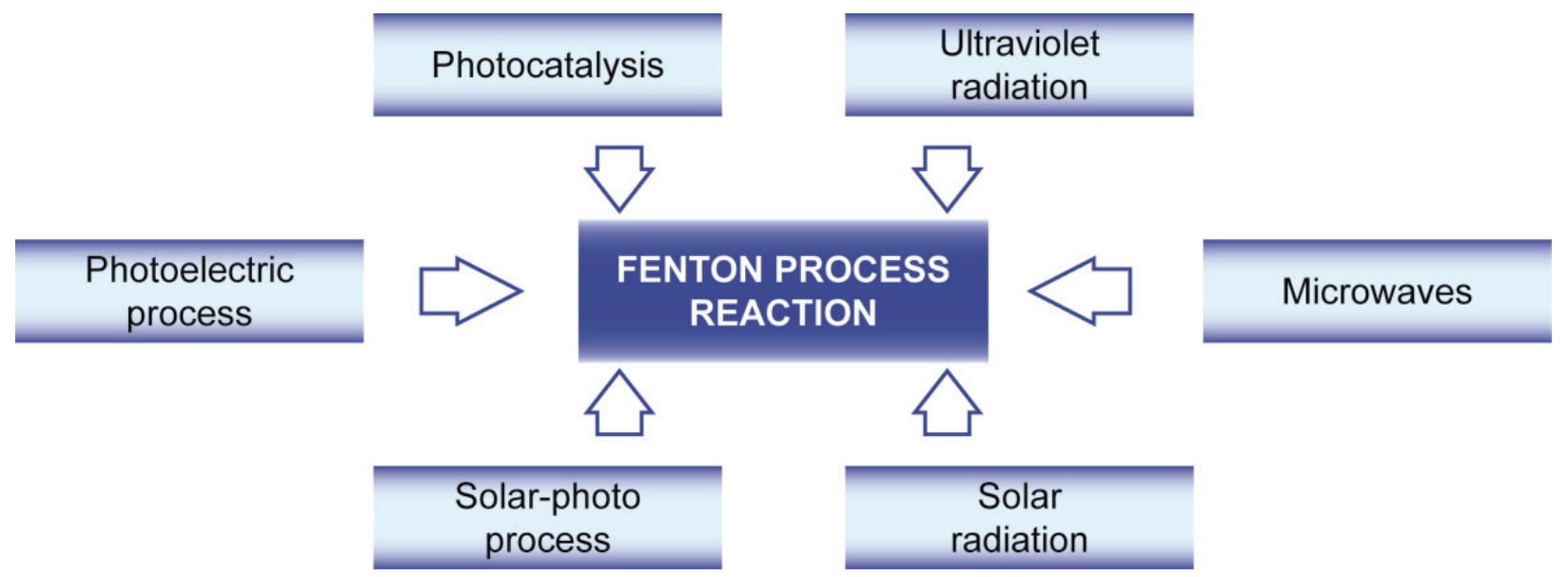

Figure 6. Technologies to be used for improvement of Fenton Process

ecotoxicity in the environment. These problems are quite prominent in developing countries due to unrestricted discharge of HWW.

\subsection{Adopted hospital wastewater treatment scenarios}

The HWW were subjected to various treatment schemes in different countries but due to lack of separate, onsite treatment facilities they remain a problem of resistant gene development around the globe. As there are no specific treatment schemes available hence combination of treatment is tried in different countries. European countries are in progress to develop and upgrade the centralized HWW treatment facilities.

Multiple parameters in designing of waste treatment technology are considered like characteristics, temperature conditions and economic feasibility of HWW. Different technologies are employed for HWW treatment including pre-treatment, MBR and other advanced oxidation processes. Due to uneven nature of HWW, different removal mechanisms would be needed. By considering the risk associated with field hospital wastewater management, its provision will be available by adopting sustainable, most economic and less energy required technologies.

\subsection{Optimal field hospital wastewater treatment scenario}

Wide application of different types of HWW treatment methods gives an opportunity to create an optimal treatment scenario for field hospital wastewater problem resolution. Experience of currently adopted HWW treatment scenarios application gives an opportunity to create combined double stage HWW treatment scenario for field hospital usage.
Biological stage of HWW treatment should be represented with MBR technology due to its simplicity and low cost. Physicochemical stage of HWW treatment should be represented with FP technology. It is applicable for low wastewater flow rate values. In addition it may be improved using effluent pre-treatment to lower cost, decrease reactor size and amount of reagents required.

\subsection{Contribution of the findings to the field and any potential applications}

By considering the criticality of hospital effluent there is no specific legislation regarding its discharge in environment. Yet wide variety of tasks to be resolved here in addition to neutralization of selected pharmaceutical compounds. In addition we should mention that developed foreground scenarios and their options will need to be adopted globally for HWW treatment. Arising HWW management and detection issues are wastewater sampling mode, observation frequency, spatial and temporal micropollutants concentration, allowable detection accuracy, reliability of results and predictions, etc.

Obtained results allow developing and implementing global field hospital wastewater treatment scenario both in legislation and technical spheres. Further technological advancement can henceforth produce a viable implication and make a strong national policy with proper legislation towards production and disposal of HWW. Their longerterm risk due to acute and regular exposure needs to be considered with proper metabolic pathways determination. 


\section{Conclusions}

As a result of analytical research we have:

1. Hospital wastewater occurs widely in field hospitals used at extreme situations. It is characterized with high risk because in comparison with domestic sewage the hospital effluent contains wide variety of toxic substances like antibiotics, radionuclides, and disinfectants.

2. Based on currently adopted HWW treatment scenarios application the optimal field hospital wastewater treatment scenario includes combination of MBR and FP technologies. It will lower cost, decrease reactor size and amount of reagents required for HWW treatment.

\section{Acknowledgements}

The authors are very thankful and acknowledge to Jamia Millia Islamia, Public Agency "National Scientific and Research Institute of Industrial Safety and Occupational Safety and Health" and Aligarh Muslim University for granting permission to publish this work in the Journal.

\section{References}

Adamcza K., Lyko S., Nafo S., Evenblij H., Cornelissen A., Igos E., Klepiszewski K., Venditti S., Kovalova L., McArdell C., Helwig K., Pahl O., Barraud O., Casellas M., Dagot C., Maftah C., Ploy M.-C. \& Stalder T., 2012, Pharmaceutical residues in the aquatic system - A challenge for the future. Insights and activities of the European cooperation project PILLS. (http://www.pills-project.eu/PILLS_summary_english.pdf).

Al A.M., Verlicchi P. \& Voulvoulis N., 2014, A framework for the assessment of the environmental risk posed by pharmaceuticals originating from hospital effluents. Science of the Total Environment 493: 54-64.

Bar-On E., Abargel A., Peleg K. \& Kreiss Y., 2013, Coping with the challenges of early disaster response: 24 years of field hospital experience after earthquakes. Disaster Medicine and Public Health Preparedness 7(5): 491-498. (https://doi.org/10.1017/dmp.2013.94).

Batelaan M.V., van den Berg E.A., Koetse E., Wortel N.C., Rimmelzwaan J. \& Vellinga S., 2013, Evaluation Report Pharmafilter: full scale demonstration in the Reinier de Graaf Gasthuis (Hospital) Delft. STOWA, Amersfoort.

Beyene H. \& Redaie G., 2011, Assessment of waste stabilization ponds for the treatment of hospital wastewater: the case of Hawassa university referral hospital. World Applied Sciences Journal 15(1): 142-150.
Boxall A.B.A., Rudd M.A., Brooks B.W., Caldwell D.J., Choi K., Hickmann S., Innes E., Ostapyk K., Staveley J.P. \& Verslycke T., 2012, Pharmaceuticals and personal care products in the environment: what are the big questions? Environmental Health Perspectives 120: 1221-1229.

Brodin T., Fick J., Jonsson M. \& Klaminder J., 2013, Dilute concentration of a psychiatric drug alter behavior of fish from natural populations. Science 339: 814815. (https://doi.org/10.1126/science.1226850).

Carraro E., Bonetta S., Bertino C., Lorenzi E., Bonetta S., \& Gilli G., 2016, Hospital effluents management: chemical, physical, microbiological risks and legislation in different countries. Journal of Environmental Management 168: 185-199.

Chartier Y., Emmanuel J., Pieper U., Prüss A., Rushbrook P., Stringer R., Townend W., Wilburn S., Zghondi R. (eds), 2014, Safe Management of wastes from healthcare activities, 2 edn. World Health Organization, Geneva, Switzerland, printed in Malta.

China, 1998, National Standard of the People's Republic of China. Integrated wastewater discharge standard GB 8978-88. Date of Approval: Oct. 4, 1996. Date of Enforcement: Jan. 1, 1998.

Chonova T., Keck F., Labanowski J., Montuelle B., Rimet F. \& Bouchez A., 2016, Separate treatment of hospital and urban wastewaters: a real scale comparison of effluents and their effect on microbial communities. Science of the Total Environment 542: 965-975.

Cizmas L., Sharma V.K., Gray C.M. \& McDonald T.J., 2015, Pharmaceuticals and personal care products in waters: occurrence, toxicity, and risk. Environmental Chemistry Letters 13: 381. (https://doi.org/10.1007/ s10311-015-0524-4).

Clean Water Act, 1972, Federal Water Pollution Control Act, 33 U.S.C. 1251 et seq. (https://www.epa.gov/ sites/production/files/2017-08/documents/federal-water-pollution-control-act-508full.pdf).

Daouk S., Chèvre N., Vernaz N., Wildmer C., Daali Y. \& Fleury-Souverain S., 2016, Dynamics of active pharmaceutical ingredients loads in a Swiss university hospital wastewaters and prediction of the related environmental risk for the aquatic ecosystems. Science of the Total Environment 547: 244-253. (https:// doi.org/10.1016/j.scitotenv.2015.12.117).

Duong H.A., Pham N.H., Nguyen H.T., Hoang T.T., Pham H.V., Pham V.C., Berg M., Giger W. \& Alder A.C., 2008, Occurrence, fate and antibiotic resistance of fluoroquinolone anti-bacterial in hospital wastewaters in Hanoi, Vietnam. Chemosphere 72: 968-973.

El-Ogri F., Ouazzani N., Boraâm F. \& Mandi L., 2016, A survey of wastewaters generated by a hospital in Marrakech city and their characterization. Desali- 
nation and Water Treatment 57: 17061-17074. (https:// doi.org/10.1080/19443994.2016.1138328).

EPA, 2016, Preliminary 2016 effluent guidelines program plan. EPA.821-R-16-001, Washington DC, USA.

EU, 1991, European Union. Council Directive 91/271/ EEC of 21 May 1991 concerning urban waste-water treatment. (https://eur-lex.europa.eu/LexUriServ/LexUriServ.do?uri=CELEX:31991L0271:EN:HTML).

EU, 1998, European Union. Commission Directive 98/15/ EC of 27 February 1998 amending Council Directive 91/271/EEC with respect to certain requirements established in Annex I thereof (Text with EEA relevance). Official Journal of the European Communities 7.3.98: I.67/29-30. (https://publications.europa.eu/en/ publication-detail/-/publication/ff7ec087-8cc3-4619bffc-b08ea4883d2c).

EU, 2008, European Union. Directive 2008/98/EC of the European Parliament and of the Council of 19 November 2008 on waste and repealing certain Directives (Text with EEA relevance). Official Journal of the European Union 22.11.2008: L 312/3. (https://eur-lex.europa.eu/ legal-content/EN/TXT/?uri=celex\%3A32008L0098).

Federal Ministry for the Environment, Nature Conservation and Nuclear Safety, 2004, Promulgation of the New Version of the Ordinance on Requirements for the Discharge of Waste Water into Waters (Waste Water Ordinance - AbwV) of 17 June 2004. BMU, Bonn, Germany. (https://www.bmu.de/fileadmin/bmuimport/ files/pdfs/allgemein/application/pdf/wastewater_ordinance.pdf).

Fekadu S., Merid Y., Beyene H., Teshome W. \& GebreSelassie S., 2015, Assessment of antibiotic and disinfectant-resistant bacteria in hospital wastewater, South Ethiopia: a cross-sectional study. Journal of Infection in Developing Countries 9(2): 149-156.

Galus M., Jeyaranjaan J., Smith E., Li H., Metcalfe C. \& Wilson J.Y., 2013a, Chronic effects of exposure to a pharmaceutical mixture and municipal wastewater in zebrafish. Aquatic Toxicolology 132-133: 212-222.

Galus M., Kirischian N., Higgins S., Purdy J., Chow J., Rangaranjan S., Li H., Metcalfe C. \& Wilson J.Y., 2013b, Chronic, low concentration exposure to pharmaceuticals impacts multiple organ systems in zebrafish. Aquatic Toxicology 132-133: 200-211.

Göbel A., McArdell C.S., Joss A., Siegrist H. \& Giger W., 2007, Fate of sulfonamides, macrolides, and trimethoprim in different wastewater treatment technologies. Science of the Total Environment 372: 361-371. (https://doi.org/10.1016/j.scitotenv.2006.07.039).

Gracepavithra K., Ponnusamy S.K., Sundarrajan P., Saravanan A. \& Naushad M., 2017, Sources and impacts of pharmaceutical components in wastewater and its treatment process: A review. Korean Journal of
Chemical Engineering 34(11): 2787-2805. (https://doi. org/10.1007/s11814-017-0255-2).

Grundfos BioBooster A/S, 2015, Private-Public Innovation Project Background and Project objectives. RPCIG Langaa, Denmark. (https://www.herlevhospital. $\mathrm{dk} /$ nythospitalherlev/nyheder-og-presse/nyheder/Documents/10988_Biobooster_Herlev_LOW_opslag.pdf).

Halpern P., Rosen B., Carasso S., Sorkine P., Wolf Y., Benedek P. \& Martinovich G., 2003, Intensive care in a field hospital in an urban disaster area: lessons from the August 1999 earthquake in Turkey. Critical Care Medicine 31(5): 1410-1414. (https://doi. org/10.1097/01.CCM.0000059439.07851.BD).

Hancock F., 1999, Catalytic strategies for industrial water re-use. Catalysis Today 53: 3-9. (https://doi. org/10.1016/S0920-5861(99)00098-X).

Hermann M., Olsson O., Fiehn R., Herrel R., Herrel M. \& Kümmerer K., 2015, The significance of different health institutions and their respective contributions of active pharmaceutical ingredients to wastewater. Environment International 85: 61-76.

ICRP, 2004, Release of patients after therapy with unsealed radionucleides ICRP Publication 94. Ann. ICRP 34(2): v-vi, 1-79.

Italy, 2011, D.P.R. 19 Ottobre 2011 n. 227. Regolamento per la semplificazione di adempimenti amministrativi in materia ambientale gravanti sulle imprese, a norma dell'articolo 49, comma 4-quater, del decreto-legge 31 maggio 2010, n. 78, convertito, con modificazioni, dalla legge 30 luglio 2010, n. 122. Pubblicato nella Gazz. Uff. 3 febbraio 2012, n. 28.

Jones-Lepp T.L. \& Stevens R., 2007, Pharmaceuticals and personal care products in biosolids/sewage sludge: The interface between analytical chemistry and regulation. Analytical and Bioanalytical Chemistry 387(4): 11731183.

Jones-Lepp T.L., Alvarez D.A., Englert B. \& Batt A., 2009, Pharmaceuticals and hormones in the environment, [in:] R.A. Meyers (ed.), Encyclopedia of Analytical Chemistry: Applications, Theory, and Instrumentation. John Wiley \& Sons Incorporated, New York, NY. 75(1): 1-59.

Jones-Lepp T.L., Sanchez C., Alvarez D.A., Wilson D.C. \& Taniguchu-Fu R.L., 2012, Point sources of emerging contaminants along the Colorado River Basin: Source water for the arid Southwestern United States. Science of the Total Environment 430: 237-245.

Jones-Lepp T.L., Sanchez C.A., Moy T. \& Kazemi R., 2010, Method development and application to determine potential plant uptake of antibiotics and other drugs in irrigated crop production systems. Journal of Agricultural and Food Chemistry 58(22): 11568-11573.

Kosma C.I., Lambropoulou D.A. \& Albanis T.A., 2010, Occurrence and removal of PPCPs in municipal and 
hospital wastewaters in Greece. Journal of Hazardous Materials 179: 804-817. (https://doi.org/10.1016/j.jhazmat.2010.03.075).

Kümmerer K. \& Helmers E., 2000, Hospital effluents as a source of Gadolinium in the aquatic environment. Environment Science \& Technology 34: 573-577.

Kümmerer K., 2009a, Antibiotics in the aquatic environment - A review - Part I. Chemosphere 75(4): 417-434

Kümmerer K., 2009b, Antibiotics in the aquatic environment - A review - Part II. Chemosphere 75(4): 435 441.

Kümmerer K., 2010, Pharmaceuticals in the environment. Annual Review of Environment and Resources 35(1): 57-75.

Lenz K., Mahnik S.N., Weissenbacher N., Mader R.M., Krenn P., Hann S., Koellensperger G., Uhl M. Knasmüller S., Ferk F., Bursch W. \& Fuerhacker M., 2007, Monitoring, removal and risk assessment of cytostatic drugs in hospital wastewater. Water Science \& Technology 56: 141-149. (https://doi.org/10.2166/ wst.2007.828).

Lien L.T.Q., Hoa N.Q., Chuc N.T.K., Thoa N.T.M., Phuc H.D., Diwan V., Dat N.T., Tamhankar A.J. \& Lundborg C.S., 2016, Antibiotics in wastewater of a rural and an urban hospital before and after wastewater treatment, and the relationship with antibiotic use-a one year study from Vietnam. International Journal of Environmental Research and Public Health 13: 1-13. (https://doi. org/10.3390/ijerph13060588).

Liu Q., Zhou Y., Chen L. \& Zheng X., 2010, Application of MBR for hospital wastewater treatment in China. Desalination 250(2): 605-608.

Maheshwari M., Yaser N.H., Naz S., Fatima M. \& Ahmad I., 2016, Emergence of ciprofloxacin resistant extended-spectrum $\beta$-lactamase-producing enteric bacteria in hospital wastewater and clinical sources. Journal of Global Antimicrobial Resistance 5: 22-25.

Mahvi A., Rajabizadeh A., Fatehizadeh A., Yousefi N., Hosseini H. \& Ahmadian M., 2009, Survey wastewater treatment condition and effluent quality of Kerman Province hospitals. World Applied Sciences Journal 7(12): 1521-1525.

Martins A.F., Vasconcelos T.G., Henriques D.M., Frank C., König A. \& Kümmerer K., 2008, Concentration of ciprofloxacin in Brazilian hospital effluent and preliminary risk assessment: A case study. CLEAN Soil, Air, Water 36: 264-269. (https://doi.org/10.1002/ clen.200700171).

Ministry of Environment and Forests, Department of Environment, Forest and Wildlife, 1986, The Environment (Protection) Act. No 29 of 1986. Government of India, New Delhi.

Naor M., Heyman S.N., Bader T. \& Merin O., 2017, Deployment of field hospitals to disaster regions: Insights from ten medical relief operations spanning three decades. American Journal of Disaster Medicine 12(4): 243-256. (https://doi.org/10.5055/ajdm.2017.0277).

Parolini M., Pedriali A. \& Binelli A., 2013, Application of a biomarker response index for ranking the toxicity of five pharmaceuticals and personal care products (PPCP) to the bivalve Dreissena polymorpha. Archives of Environmental Contamination and Toxicology 64: 439-447.

Prabhasankar V.P., Joshua D.I., Balakrishna K., Siddiqui I.F., Taniyasu S., Yamashita N., Kannan K., Akiba M., Praveenkumarreddy Y. \& Guruge K.S., 2016, Removal rates of antibiotics in four sewage treatment plants in South India. Environmental Science and Pollution Research Int. 23(9): 8679-8685. (https://doi. org/10.1007/s11356- 015-5968-3).

Prado T., Silva D.M., Guilayn W.C., Rose T.L., Gaspar A.M.C. Miagostovich M.P., 2011, Quantification and molecular characterization of enteric viruses detected in effluents from two hospital wastewater treatment plants. Water Research 45: 1287-1297. (https://doi. org/10.1016/j.watres.2010.10.012).

Rogers H.R., 1996, Sources, behaviour and fate of organic contaminants during sewage treatment and in sewage sludges. Science of the Total Environment 185: 3-26. (https://doi.org/10.1016/0048-9697(96)05039-5).

Santos L.H., Gros M., Rodriguez-Mozaz S., Delerue-Matos C., Pena A., Barceló D. \& Montenegro M.C., 2013, Contribution of hospital effluents to the load of pharmaceuticals in urban wastewaters: identification of ecologically relevant pharmaceuticals. Science of the Total Environment 461-462: 302-316.

Shrestha R.R., Haberl R. \& Laber J., 2001a, Constructed wetland technology transfer to Nepal. Water Science \& Technology 43: 345-350.

Shrestha R.R., Haberl R., Laber J., Manandhar R. \& Mader J., 2001b, Application of constructed wetlands for wastewater treatment in Nepal. Water Science \& Technology 44: 381-386.

Sim W.J., Kim H.Y., Choi S.D., Kwon J.H. \& Oh J.E., 2013, Evaluation of pharmaceuticals and personal care products with emphasis on anthelmintics in human sanitary waste, sewage, hospital wastewater, livestock wastewater and receiving water. Journal of Hazardous Materials 248-249: 219-227.

Sokolov D., Sobyna V., Vambol S. \& Vambol V., 2018, Substantiation of the choice of the cutter material and method of its hardening, working under the action of friction and cyclic loading. Archives of Materials Science and Engineering 94(2): 49-54. (https://doi. org/10.5604/01.3001.0012.8658).

Tambosi J.L., de Sena R.F., Gebhardt W., Moreira R.F.P.M., José H.J. \& Schröder H.F., 2009, Physicochemical and advanced oxidation processes - A comparison of elim- 
ination results of antibiotic compounds following an MBR treatment. Ozone: Science \& Engineering 31: 428435. (https://doi.org/10.1080/01919510903324420).

The Socialist Republic of Vietnam, 2014, Law on environmental protection. No. 55/2014/QH13. Official Gazette Issue nos. 11-12/July 2014: 5-63. Vietnam Law and Legal Forum, Hanoi. (https://www.informea.org/ sites/default/files/legislation/vie167836.pdf).

Vambol S., Vambol V., Kondratenko O., Koloskov V. \& Suchikova Y., 2018, Substantiation of expedience of application of high-temperature utilization of used tires for liquefied methane production. Journal of Achievements in Materials and Manufacturing Engineering 87(2): 7784. (https://doi.org/10.5604/01.3001.0012.2830).

Vambol S., Vambol V., Sundararajan M. \& Ansari I., 2019, The nature and detection of unauthorized waste dump sites using remote sensing. Ecological Questions 30(3): 1-17. (https://doi.org/10.12775/EQ.2019.018).

Verlicchi P. \& Zambello E., 2016, Predicted and measured concentrations of pharmaceuticals in hospital effluents. Examination of the strengths and weaknesses of the two approaches through the analysis of a case study. Science of the Total Environment 565: 82-94.
Verlicchi P., Al Aukidy M., Galletti A., Petrovic M. \& Barceló D., 2012a, Hospital effluent: investigation of the concentrations and distribution of pharmaceuticals and environmental risk assessment. Science of the Total Environment 430: 109-118.

Verlicchi P., Aukidy M. \& Zambello E., 2012b, Occurrence of pharmaceutical compounds in urban wastewater: Removal, mass load and environmental risk after a secondary treatment - A review. Science of the Total Environment 429: 123-155. (https://doi.org/10.1016/j. scitotenv.2012.04.028).

Verlicchi P., Galletti A. \& Masotti L., 2010a, Management of hospital wastewaters: The case of the effluent of a large hospital situated in a small town. Water Science \& Technology 61: 2507-2519. (https://doi.org/10.2166/ wst.2010.138).

Verlicchi P., Galletti A., Petrovic M. \& Barceló D., 2010b, Hospital effluents as a source of emerging pollutants: an overview of micropollutants and sustainable treatment options. Journal of Hydrology 389: 416-428.

Yu J., Li Q. \& Yan S., 2013, Design and running for a hospital wastewater treatment project. Advanced Materials Research 777: 356-359. 